\title{
Purification and characterization of Moschatin, a novel type I ribosome-inactivating protein from the mature seeds of pumpkin (Cucurbita moschata), and preparation of its immunotoxin against human melanoma cells
}

\author{
Heng Chuan Xia, Feng Li, Zhen Li, Zu Chuan Zhang*
}

Key Laboratory of Proteomics, Institute of Biochemistry and Cell Biology, Shanghai Institutes for Biological Sciences, Chinese Academy of Sciences, Shanghai 200031, China.E-mail: zhangzc@sunm.shcnc.ac.cn

\begin{abstract}
A novel ribosome-inactivating protein designated Moschatin from the mature seeds of pumpkin (Cucurbita moschata) has been successively purified to homogeneity, using ammonium sulfate precipitation, CM-cellulose 52 column chromatography, Blue Sepharose CL-6B Affinity column chromatography and FPLC size-exclusion column chromatography. Moschatin is a type 1 RIP with a $\mathrm{pI}$ of 9.4 and molecular weight of $\sim 29 \mathrm{kD}$. It is a rRNA Nglycosidase and potently blocked the protein synthesis in the rabbit reticulocyte lysate with a $\mathrm{IC}_{50}$ of $0.26 \mathrm{n} M$. Using the anti-human melanoma McAb Ng76, a novel immunotoxin Moschatin-Ng76 was prepared successfully and it efficiently inhibited the growth of targeted melanoma cells $\mathrm{M}_{21}$ with a $\mathrm{IC}_{50}$ of $0.04 \mathrm{n} M, 1500$ times lower than that of free Moschatin. The results implied that Moschatin could be used as a new potential anticancer agent.
\end{abstract}

Keywords: ribosome-inactivating protein (RIP), Moschatin, immunotoxin.

\section{INTRODUCTION}

Plant RIPs are the majority member of RIP superfamily, and widely distribute in different plants and various tissues, in some cases, even a large quantity in the seeds[1,2]. They are shown to have diversified biological functions, such as antiviral (anti-HIV), antifungal and insecticidal properties[3-6]. They are rRNA N-glycosidase that site-specifically cleaves the N-glycosidic bond of a specific adenosine residue $\left(\mathrm{A}^{4324}\right)$ in a highly conserved loop (the sarcin/ricin domain) of the largest ribosomal RNA. This modification leads to the specific adenine being removed and thus the protein synthesis is blocked[7,8].

Plant RIPs are classified into three groups based on their primary structures[9]:Type 1 RIPs, such as Trichosanthin (TCS), are single-chain basic proteins with a molecular weight of $\sim 30 \mathrm{kD}$; Type 2 RIPs, like ricin, are two-chain proteins that consist of an A-chain with

*Corresponding author: Zu Chuan ZHANG

Tel: 0086-21-54921281; Fax: 0086-21-54921011;

E-mail: zhangzc@sunm.shenc.ac.cn

Abbreviations: RIP, ribosome-inactivating protein; IT, immunotoxin; $\mathrm{KD}$, kilodalton; PAGE, polyacrylamide gel electrophoresis; IEF, isoelectric focusing electrophoresis; McAb, monoclonal antibody.

Received Dec-6-2002 Revised June-2-2003 Accepted July-15-2003
rRNA N-glycosidase activity through a disulfide bond linked to a lectin-like B chain, the molecular weight of each chain being of $\sim 30 \mathrm{kD}$; Type 3 RIPs, like maize RIP, require natural proteolysis processing to transform the inactive precursors to mature RIPs.

RIPs are suitable probes to investigate the structure and function of ribosome and the interactions between protein and RNA. They are also used to prepare selective cell-killing agents, such as immunotoxins[10], for their highly cytotoxic activities when transferred into cytoplasm. Up to now, more than 80 different RIPs from a variety of plants have been characterized, yet there has been no report about RIPs purified from pumpkin seeds. We report here that a novel Type 1 RIP named Moschatin from the mature seeds of pumpkin has been purified and characterized, and its immunotoxin has also been prepared and successfully applied to selectively kill human melanoma cells in vitro.

\section{MATERIALS AND METHODS}

\section{Materials}

The mature seeds of pumpkin (Cucurbita moschata) were purchased from Shaoxing Seeds Co. (Shaoxing, Zhejiang, China). Crystal TCS was purchased from Jinshan Pharmaceutical Factory (Shanghai, China). The hybridoma cell line secreting anti-human melanoma $\mathrm{Ng} 76$ 
(IgG2b) was provided by Dr. YJ Huang (University of Columbia, USA). Ng76 was purified from mouse ascites that contained this antibody by ammonium sulfate precipitation ( $50 \%$ saturation) and DE-cellulose 11 column chromatography. Human melanoma cell line M21 was provided by Dr. YJ Huang (University of Columbia, and the HeLa cell line were obtained from the late Prof. N.O.Kaplan (University of California at San Diego, San Diego, CA, USA). CMcellulose 52 was the product of Whatman Co. Sephacryl S-200, Blue Sepharose CL-6B, FPLC system and Superose 12 HR 30/30 column were obtained from Pharmacia Co. The cross-linking reagents $\mathrm{N}$ Succinimidyl 3-(2-pyridyldithio) propionate (SPDP) and 2iminothiolane (2-IT) were purchased from Sigma Co. All other reagents were of analytical grade.

\section{Purification of Moschatin}

After the shelled pumpkin seeds were crushed and degreased by ice-cold ether, the seed powder was obtained and extracted by 10 volumes of buffer A ( $20 \mathrm{mM}$ phosphate buffer, $\mathrm{pH} 7.2,0.2 \mathrm{M} \mathrm{NaCl}$ ) with gently stirring at $4^{\circ} \mathrm{C}$ overnight. Then the homogenate was centrifuged $\left(9,000 \mathrm{~g}, 4^{\circ} \mathrm{C}, 30 \mathrm{~min}\right)$, and the supernatant as the crude extract was pooled and the proteins were precipitated gradually by ammonium sulfate (AS). The mixture was centrifuged $\left(9,000 \mathrm{~g}, 4^{\circ} \mathrm{C}\right.$, $30 \mathrm{~min}$ ) when the AS saturation reached $50 \%$. The supernatant was collected and the AS was added continuously untill its saturation reached $85 \%$, then the pellet was obtained by centrifugation $(9,000 \mathrm{~g}$, $\left.4^{\circ} \mathrm{C}, 30 \mathrm{~min}\right)$. The pellet was dissolved in buffer B ( $5 \mathrm{mM} \mathrm{PB}, \mathrm{pH} 7$. 0 ) and then extensively dialyzed against the same buffer. After centrifugation to remove insoluble materials, the supernatant was applied to a CM-cellulose 52 column $(15.0 \mathrm{~cm} \times 2.0 \mathrm{~cm})$ preequilibrated with buffer $\mathrm{B}$, and then the column was eluted with a linear gradient of $0-0.6 \mathrm{M} \mathrm{NaCl}$ in buffer B. The fraction $(3.0 \mathrm{ml} /$ tube $)$ containing Moschatin was pooled and dialyzed against buffer C (15 mM Tris$\mathrm{HCl}, \mathrm{pH} 7.5)$, then applied to a Blue Sepharose CL-6B column (8.0 $\mathrm{cm} \times 1.0 \mathrm{~cm}$ ) preequilibrated with buffer $\mathrm{C}$, and the absorbed proteins were released by buffer $\mathrm{C}$ containing $0.3 \mathrm{M} \mathrm{NaCl}$. The active fraction ( $3.0 \mathrm{ml} /$ tube) was further purified by FPLC on a Superose $12 \mathrm{HR}$ 30/ 30 column, using phosphate-buffered saline (PBS, pH 7.2) as the eluent, and the resulted homogenous protein $(2.0 \mathrm{ml} /$ tube $)$ was designated as Moschatin.

\section{Determination of Molecular weight and pI of Moschatin}

The molecular weight of Moschatin was determined by FPLC gel filtration and SDS-PAGE. Its pI value was determined by isoelectrophoresis fousing (IEF). These assays were performed according to the method as described by Gao et al[11].

\section{Determination of $N$-terminal amino acid sequence of}

\section{Moschatin}

The homogenous Moschatin was subjected to SDS-PAGE, and Western blotting was performed at $40 \mathrm{~mA}$ for $1 \mathrm{~h}$ using a polyvinylidene fluoride (PVDF) membrane and a semi-dry transfer cell (Bio-Rad USA). The Moschatin band used for sequencing was cut out and air-dried. Amino acid sequencing was conducted with an Applied Biosystems Model 491 Edman degradation unit and an HP 1000 HPLC system.

\section{Determination of rRNA N-glycosidase activity of}

\section{Moschatin and its inhibition to protein synthesis}

The rRNA N-glycosidase activity of Moschatin was determined using rabbit liver ribosomes as substrate, according to the method of Endo et al[12]. The inhibitory activity of Moschatin to protein synthesis was determined by the method of Ying et al[13].

\section{Preparation of immunotoxin (Moschatin- $\mathrm{Ng} 76$ )}

The preparation of Moschatin-Ng76 was carried out according to the method as described by Gao et al[14]. SPDP modified $\mathrm{Ng} 76$ and 2-IT modified Moschatin/TCS were reacted at $4^{\circ} \mathrm{C}$ for $72 \mathrm{~h}$ in nitrogen atmosphere, and then the reaction mixture was applied on a Sephacryl S-200 column $(100.0 \mathrm{~cm} \times 1.1 \mathrm{~cm})$. The column was eluted with PBS (pH 7.2) and the fraction containing immunotoxin (determined by SDS-PAGE) was collected, sterilized and stored at $4^{\circ} \mathrm{C}$.

\section{Cytotoxic activity of immunotoxin (Moschatin-Ng76)} against human melanoma cells

The cytotoxic activity of immunotoxin against human melanoma cells was performed by MTT method[15], and 5 different samples (Ng76, TCS, Moschatin, TCS-Ng76 and Moschatin-Ng76) were analyzed. Target cells $\mathrm{M}_{21}$ and non-target cells Hela (negative control) were distributed into 96 -well cell culture plate $(5,000$ cells/well) in 0 . $18 \mathrm{ml}$ DMEM medium containing $8 \%$ new-born calf serum, and cultured in $5 \% \mathrm{CO}_{2}$ at $37^{\circ} \mathrm{C}$ for $4 \mathrm{~h}$, then samples with designed concentration were added $(0.02 \mathrm{ml}$ per well) to the culture medium respectively, and continuously cultured in the same condition for 60 h. The surviving cells were measured by MTT method.

\section{RESULTS}

\section{Purification and characterization of Moschatin}

The seed powder of pumpkin was fully extracted, then the proteins were fractioned by ammonium sulfate precipitation. The fraction that contained RIP activity was collected and then applied to a CM-cellulose 52 column. Fig 1A shows the chromatographic profile. The fraction containing Moschatin was pooled and dialyzed, then subjected to a Blue Sepharose CL-6B column (Fig 1B). The first protein peak (Fig 1B) that contained Moschatin was collected and further purified by FPLC Superose 12 column (Fig 1C). About $8.0 \mathrm{mg}$ of homogenous Moschatin was finally obtained from $100 \mathrm{~g}$ of seeds. The pure Moschatin appeared as a single peak with a retention time of $61.6 \mathrm{~min}$ in FPLC Superose $12 \mathrm{HR}$ gel filtration, and its molecular weight was determined to be $\sim 29 \mathrm{kD}$ based on the retention time of standard protein markers (Fig 1D). As shown in Fig 2, the purified Moschatin also showed a single band with a molecular weight of $\sim 29 \mathrm{kD}$ 
by SDS-PAGE under both reducing and non-reducing conditions. The pI value of Moschatin was 9.4 determined by IEF (similar to TCS, data not shown). Its Nterminal amino acid sequence is determined to be NH2N-V-R-F-D-L-S-G-A-T.

rRNA N-glycosidase activity of Moschatin and its inhibition to protein biosynthesis

It has been demonstrated that all plant RIPs are rRNA N-glycosidase and catalytically cleave the N-glycosidic bond of a specific adenosine residue, $\mathrm{A}^{4324}$, in rat liver 28S rRNA. After further treatment with acidic aniline, the phosphodiester bond was split at depurination site and a specific RNA fragment about 400 nucleotides, named R-fragment, was released. As shown in Lane 4

A
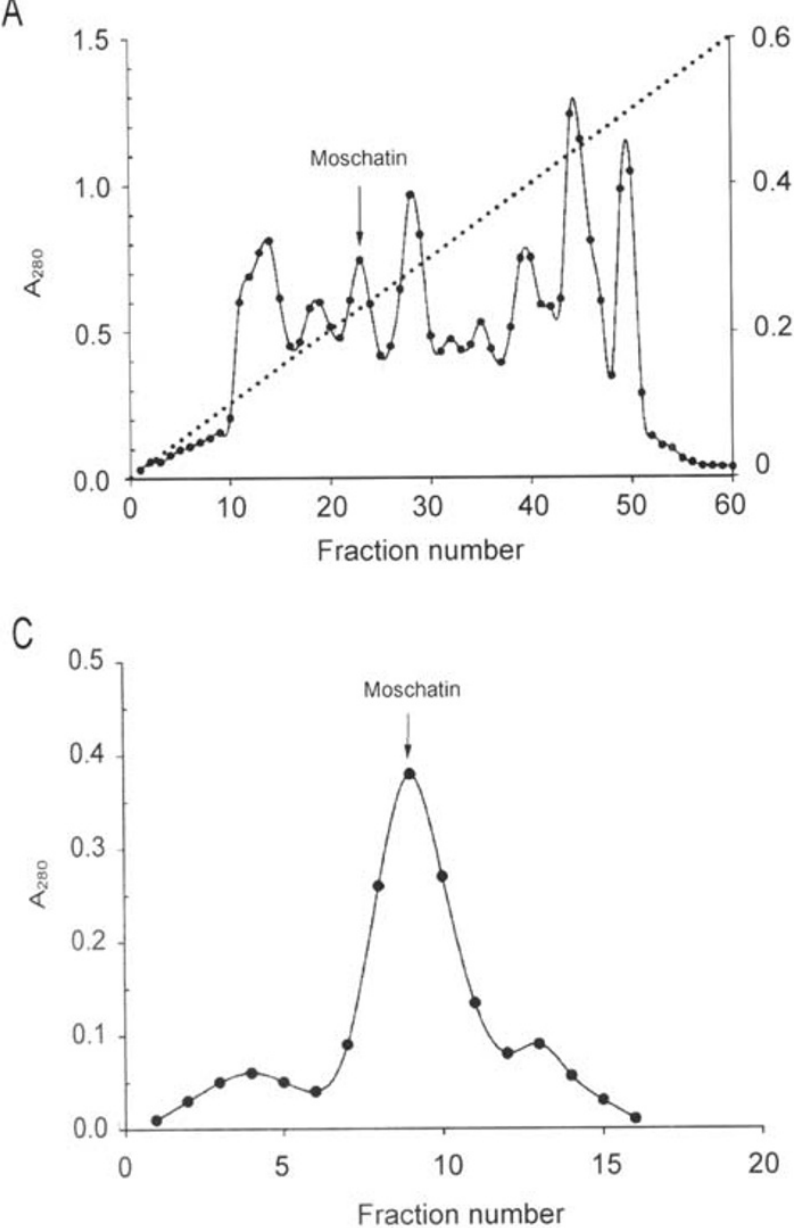

in Fig 3, the rabbit liver ribosomes were treated by only 10 ng Moschatin and acidic aniline, a clear specific band of about 400 nucleotides (R-fragment) was appeared in the urea-PAGE graph. The same band was revealed by TCS (Lane 2, Fig 3), which is a rRNA N-glycosidase and used as positive control. As shown in Fig 4, in the cell-free protein synthesis system, Moschatin displayed a stronger inhibitory activity compared with that of TCS. Their IC50 values are $0.26 \mathrm{nM}$ and $0.55 \mathrm{nM}$ respectively. These results suggest that Moschatin can be used as a toxin moiety for immunotoxin construction.

\section{Preparation of Immunotoxin Moschatin- $\mathrm{Ng} 76$ and its} cytotoxic activity against human melanoma cells
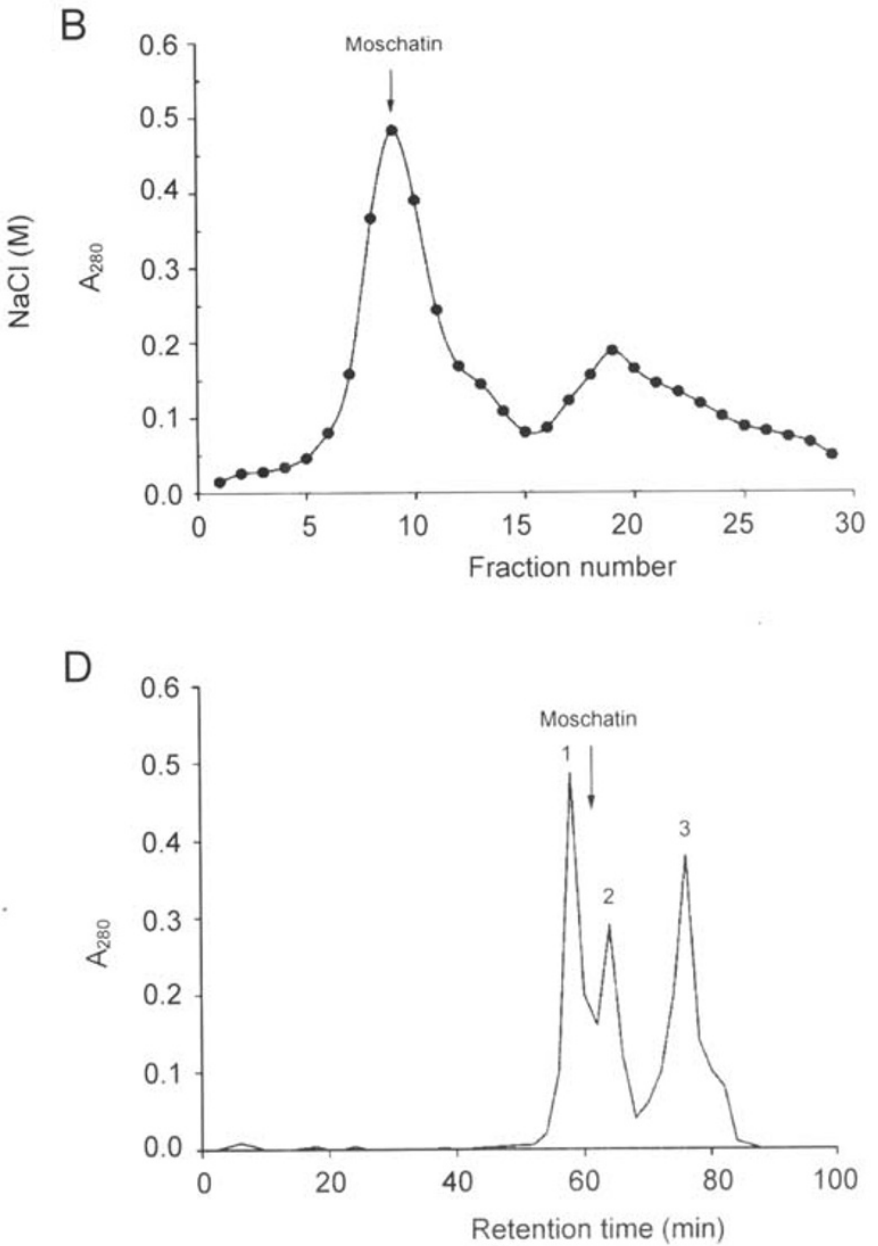

Fig 1. Purification of Moschatin from the mature seeds of pumpkin. The detailed experimental procedures are described in Materials and Methods. The seeds were crushed, degreased and extracted, and the proteins were fractioned by ammonium sulfate precipitation. The fraction containing Moschatin was applied to a CM-cellulose 52 column (A). Fraction containing RIP activities was pooled and subjected to a Blue Sepharose CL-6B column (B). The active fraction was collected and further purified by a FPLC Superose 12 HR $30 / 30$ column (C). (D) Determination of molecular weight of Moschatin by FPLC Superose $12 \mathrm{HR}$ gel filtration. Standard protein marker: 1, $40 \mathrm{kD}, 58.0$ min; 2, $25.7 \mathrm{kD}, 64.0 \mathrm{~min} ; 3,14.4 \mathrm{kD}, 75.2 \mathrm{~min}$. The arrow indicates the retention time of Moschatin, $61.6 \mathrm{~min}$. The molecular weight of Moschatin can be calculated based on the linear relation of $\log _{10}(\mathrm{MW})$ Vs retention time. 
In a previous report, TCS has been successfully constructed into immunotoxin and applied to destroy human liver cancer cells[16]. In order to observe anti-melanoma effect of Moschatin-Ng76, an immunotoxin TCS$\mathrm{Ng} 76$ was also constructed simultaneously. After exces-

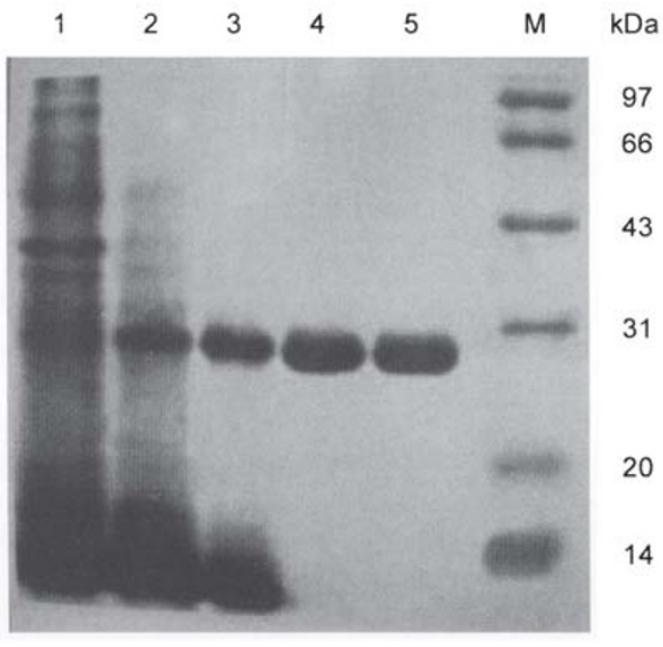

Fig 2. $12.5 \%$ SDS-PAGE analysis of Moschatin. M, molecular weight markers; Lane 1, crude extract; Lane 2, 50\%-85\% ammonium sulfate precipitation; Lane 3, CM-cellulose 52 column chromatography; Lane 4, Blue sepharose CL-6B affinity column chromatography, Moschatin without treatment of $\beta$-mercaptoethanol; Lane 5, FPLC Superose 12 column chromatography, Moschatin treated with b-mercaptoethanol.

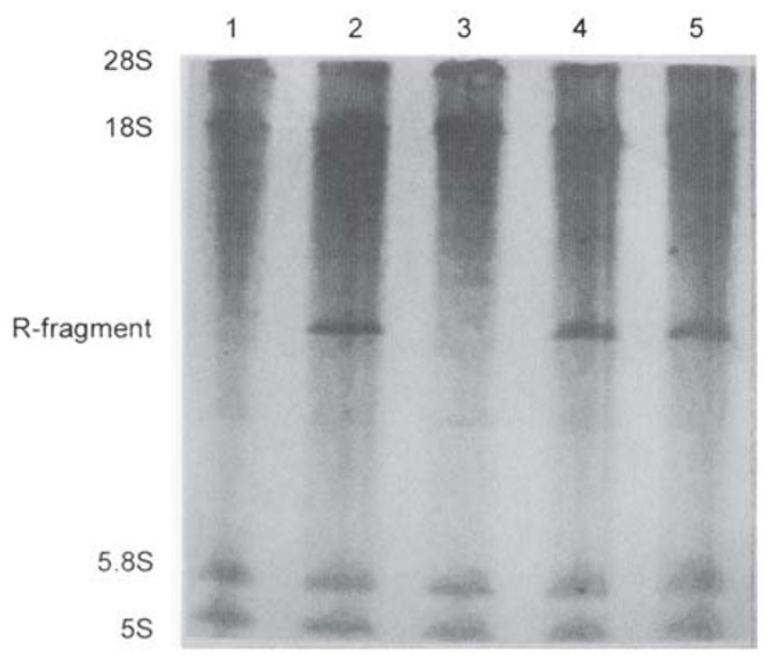

Fig 3. The rRNA N-glycosidase activity assay of Moschatin. The rRNA N-glycosidase activity assay was performed as described by Endo[7]. Lane 1, $10 \mathrm{ng}$ TCS without acid aniline treatment (negative control); Lane 2, $10 \mathrm{ng}$ TCS treated with acid aniline (positive control); Lane 3, 10 ng Moschatin without acid aniline treatment; Lane 4, $10 \mathrm{ng}$ Moschatin treated with acid aniline; Lane 5, $8 \mathrm{ng}$ Moschatin treated with acid aniline. sive amount of 2-IT modified Moschatin/control; TCS were mixed with SPDP modified $\mathrm{Ng} 76$ and fully reacted, the two reaction mixtures were respectively applied on Sephacryl S-200 size exclusion column $(100.0 \mathrm{~cm} \times 1.1$ $\mathrm{cm}$ ). The fraction containing immunotoxin (TCS-Ng76/ Moschatin-Ng76) which were determined by SDSPAGE, was collected, sterilized and kept at $4{ }^{\circ} \mathrm{C}$ for analysis.

The target cells M21 and non-target cells Hela were treated with different concentrations of each sample (Ng76, TCS, Moschatin, TCS-Ng76 and Moschatin$\mathrm{Ng} 76$ ). It is quite evident that Moschatin-Ng76 showed potent inhibition against target melanoma cells M21 (Fig $5 \mathrm{~A}$ ) with a $\mathrm{IC}_{50}$ of $0.04 \mathrm{nM}, 1500$ times lower than that of free Moschatin $\left(\mathrm{IC}_{50}: 59.0 \mathrm{nM}\right)$, and was more toxic than that of TCS-Ng76 $\left(\mathrm{IC}_{50}: 0.24 \mathrm{n} M\right)$. Yet free $\mathrm{McAb}$ $\mathrm{Ng} 76$ had very low inhibitory effect even at the level of 1000 nM. Like TCS-Ng76, Moschatin-Ng76 also showed low cytotoxic activity on non-target Hela cells. Above results indicated that immunotoxin Moschatin-Ng76 was an effective and specific reagent against human melanoma cells.

\section{DISCUSSION}

Plant RIPs have been shown to have multiple functions, such as antiviral, antifungal and insecticidal properties. Therefore, they may play important roles in plant defense system, and may have great potential in medicinal or agronomic applications, such as anticancer drugs or

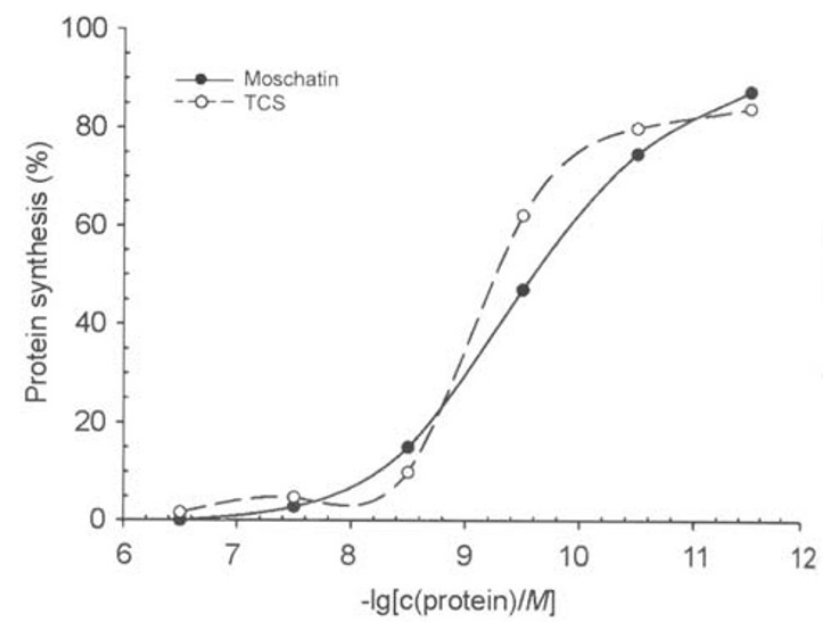

Fig 4. The protein synthesis inhibitory activities of Moschatin. This assay was performed as described by Ying et al[13], using a rabbit reticulocyte lysate system. Each point was the mean value of three parallel experiments with the deviation less than $10 \%$. 

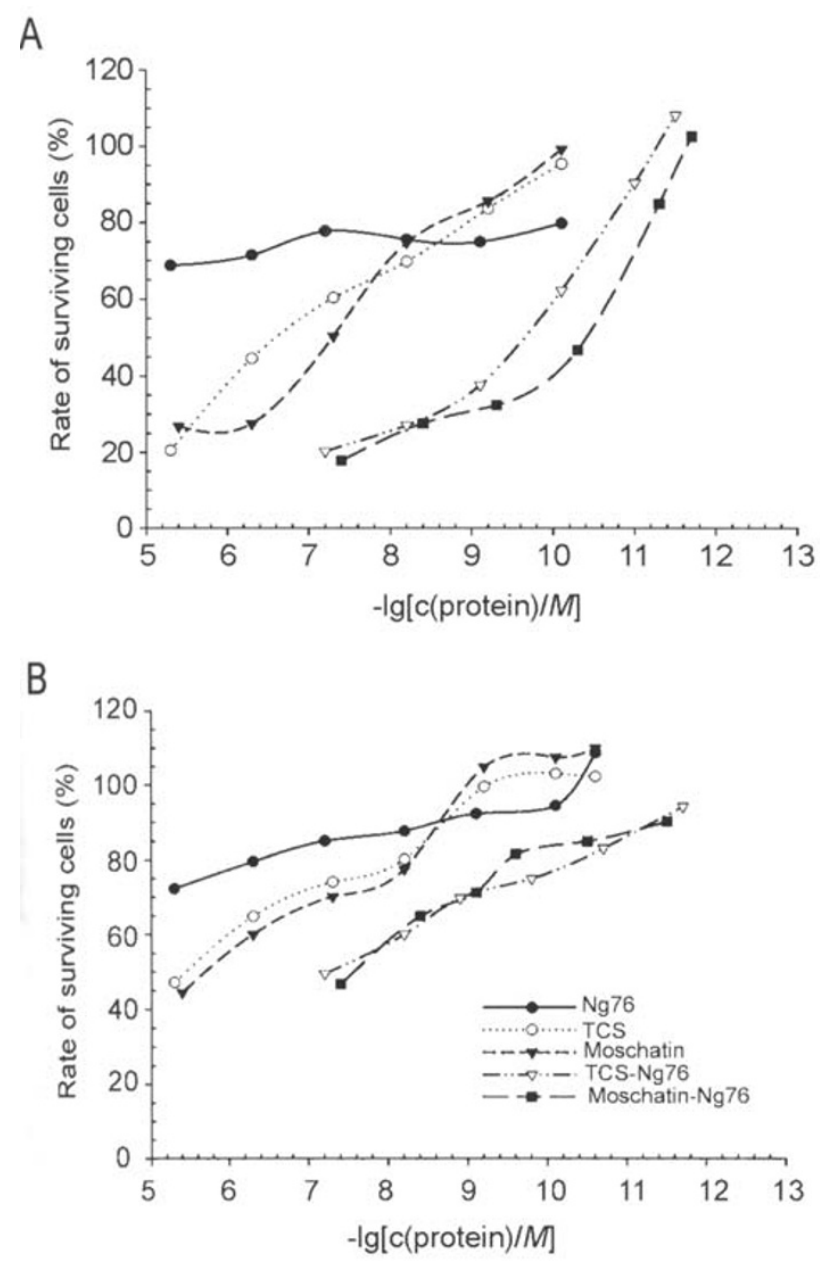

Fig 5. The Cytotoxic activities analysis of immunotoxin MoschatinNg76. Targeted human melanoma cells M21 (A) and non-targeted Hela cells $(\mathbf{B})$ were treated with designed concentration of samples respectively, and the surviving cells were measured by MTT method. In above figures each point was the mean value of three parallel experiments with the deviation less than $10 \%$.

antiviral transgenic tobacco, etc[17-19]. Many researchers are excited to make vigorous efforts for their purification, characterization and investigation of their possible uses[20-22]. In present work, a novel RIP designated as Moschatin has been isolated and characterized from the mature seeds of pumpkin. Similar to other Type 1 RIP, it is a basic single-chain protein with a $\mathrm{pI}$ of 9.4 and a molecular weight of $\approx 29 \mathrm{kD}$. It appeared as a single band in SDS-PAGE under both reducing and nonreducing conditions. It showed potent rRNA N-glycosidase activity and stronger inhibitory activity to protein synthesis than that of TCS. Up to now, there has no report about RIP purified from the seeds of pumpkin (Cucurbita moschata). The N-terminal amino acid sequence of Moschatin is determined to be NVRFDLSGAT. By searching GenBank we find that there is no other RIPs which has similar N-terminal amino acid sequence to that of Moschatin, except a $26 \mathrm{kD}$ RIP from sarcocarp of Cucurbita pepo. All these results suggest that Moschatin is a novel Type 1 RIP.

TCS, as a strong single chain RIP, has been constructed into immunotoxin and successfully applied to kill human liver cancer cells. In the present study, two antimelanoma immunotoxins were constructed in parallel by using TCS and Moschatin as the toxin moiety respectively. It was found that Moschatin-Ng76 had stronger toxicity against M21 cells than that of TCS-Ng76 (Fig 5). This result may suggest the alternative clinical use of the immunotoxins, so as to reduce immunologic rejection against its toxin moiety. Some RIPs exist abundantly in plant seeds and may play roles as storage proteins[23] for their development, and some of them showed antifungal activities. The possible antifungal activity of Moschatin was also investigated, using eight species of harmful agricultural fungi that were often used in antifungal test (Pellicularia sasakii Ito, Alternaria alternate (Fries) Keissler, Phytophthora boehneriae, Fusarium graminearum Schw, Fusarium moniliforme, Verticillum dahliae, Pellicularia sasakoo Ito, Fusarium oxysporum of Cucumis melo L.). The results showed that Moschatin had no inhibitory activity against the growth of above funguses even at concentration of $1.0 \mathrm{mg} / \mathrm{ml}$ (10 ml per test, data not shown) which is usually the maximum concentration for most antifungal proteins to achieve their strongest activities[24,25]. The real biological role of Moschatin is still an intriguing issue which needs further efforts to resolve it. The yield of Moschatin purified from mature pumpkin seeds was relatively low. Therefore, it would be helpful to clone, express and modify its gene in order to explore its structure-function relationship and its real biological functions.

\section{ACKNOWLEDGEMENTS}

This work was supported by a grant from Knowledge Innovation Program of Chinese Academy of Sciences, (No. KSCX2-3-06).

\section{REFERENCES}

1 Barbieri L, Battelli MG, Strpe F. Ribosome-inactivating proteins 
from plants. Biochim Biophys Acta 1993; 154:237-82.

2 Liu RS, Yang JH, Liu WY. Isolation and enzymatic characterization of lamjapin, the first ribosome-inactivating protein fromcryptogamic algal plant (Laminaria japonica A). Eur J Biochem 2002; 269(19):4746-52.

3 Au TK, Collins RA, Lam TL, Ng TB, Fong WP, Wan DC. The plant ribosome inactivating proteins luffin and saporin are potent inhibitors of HIV-1 integrase. FEBS Lett 2000; 471:169-72.

4 Nielsen K, Payne GA, Boston RS. Maize ribosome-inactivating protein 1 has antifungal activity against Aspergillus flavus and Aspergillus nidulans. Mol Plant-Microbe Interact 2001; 14:16472.

5 Zhou X, Li XD, Yuan JZ, Tang ZH, Liu WY. Toxicity of cinnamomin - a new type II ribosome-inactivating protein to bollworm and mosquito. Insect Biochem Mol Biol 2000; 30(3): 259-64.

6 Stebbing J, Patterson S, Gotch F. New insights into the immunology and evolution of HIV. Cell Res 2003; 13(1):1-7.

7 Endo Y, Mitsui K, Motizuki M, Tsurugi K. The mechanism of action of ricin and related toxic lectins on eukaryotic ribosomes: the site and the characteristics of the modification in 28s ribosomal RNA caused by the toxins. J Biol Chem 1987; 262:5908-12.

8 Nilsson L, Asano K, Svensson B, Poulsen FM, Nygard O. Reduced turnover of the elongation factor EF-1 ribosome complex after treatment with the protein synthesis inhibitor II from barley seeds. Biochim Biophys Acta 1986; 868:62-70.

9 Nielsen K, Boston RS. Ribosome-inactivating proteins: a plant perspective. Annu Rev Plant Physiol Plant Mo Biol 2001; 52:785816.

10 Kreitman RJ. Immunotoxins in cancer therapy. Curr Opin Immunol 1999; 11:570-78.

11 Gao WD, Cao HT, Ji RH, Zhang ZC. Isolation and Characterization of protein-biosynthesis inhibiting proteins from seeds of luffa cylindrica. Acta Biochimica et Biophysica 1994; 26(3):28995.

12 Endo Y, Tsurugi K. RNA N-glycosidase activity of ricin A-chain: mechanism of action of the toxic lectin ricin on eukaryotic ribosomes. J Biol Chem 1987; 262:8128-30.

13 Ying WB, Zhang ZF, Wang QC. Measurement of inhibition of protein biosynthesis in a rabbit reticulocyte lysate. Progress in biochemistry and Biophysics 1989; 16(6):467-70

14 Gao WD, Zhang RP, Cao HT, Ji RH, Zhang ZC. Construction of luffin A immunotoxin and its in vitro inhibition against human melanoma cell M21. Chinese Science Bulletin 1994; 39(11):9503.

15 Zhang RP, Xiong CY, Yan M, Zhang ZC. In vitro inhibition of human melanoma cells by immunotoxin luffin B-Ng76. Acta Biochimica et Biophysica 1998; 30(6):561-4.

16 QC Wang, WB Ying, H Xie, ZC Zh, ZH Yang, LQ Ling. Trischosanthin-monoclonal antibody conjugate specifically cytotoxic to human hepatoma cells in vitro. Cancer Res 1991; 51: 3353-5.

17 Kreitman RJ. Toxin-labeled monoclonal antibodies. Curr Pharm Biotechnol 2001; 2(4):313-25.

18 Barbieri L, Bolognesi A, Stirpe F. Purification and conjugation of type 1 ribosome-inactivating proteins. Methods Mol Biol 2001; 166:71-85.

19 Krishnan R, McDonald KA, Dandekar AM, Jackman AP, Falk B. Expression of recombinant trichosanthin, a ribosome-inactivating protein, in transgenic tobacco. J Biotechnol 2002; 97(1):69-88.

20 Gasperi CA, Barbieri L, Battelli MG, Stirpe F. On the distribution of ribosome-inactivating proteins amongst plant. J Nat Prod 1985; 48:446-54.

21 Pastan I, Fitzgerald D. Recombinant toxins for cancer treatment. Science 1991; 254:1173-76.

22 Frankel A E, FitzGerald D, Siegall C, Press OW. Advances in immunotoxin biology and therapy: a summary of the Fourth International Symposium on Immunotoxins. Cancer Res 1996; 56: 926-32.

23 Liu RS, Wei GQ, Yang Q, He WJ, Liu WY. Cinnamomin, a type II ribosome-inactivating protein, is a storage protein in the seed of the camphor tree (Cinnamomum camphora). Biochem J 2002; 362(Pt 3):659-63.

24 Leah R, Tommerup H, Svendsen I, Mundy J. Biochemical and molecular characterization of three barley seed proteins with antifungal properties. J Biol Chem 1991; 266(3):1564-73.

25 Hao JJ, Xu Y, Geng CD, et al. Purification of alpha-sarcin and an antifungal protein from Aspergillus giganteus by blue sepharose CL-6B affinity chromatography. Protein Expr Purif 1998; 14(2): 295-301 